\title{
Are they sinners or saints? A multi-level investigation of hypocrisy in organisational and employee pro-environmental behaviours
}

\author{
Lei Yang ${ }^{\mathrm{a}}$ (Email: lei.yang@qmul.ac.uk) \\ Danae Manikab (Email: danae.manika@ncl.ac.uk) \\ Andromachi Athanasopoulou ${ }^{\mathrm{a}}$ (Email: a.athanasopoulou@qmul.ac.uk)
}

\begin{abstract}
Research tends to examine corporate and individual hypocrisy in the context of proenvironmental behaviour (PEB) separately, and thus the underlying drivers of such behaviour as the product of contextual influences are yet to be examined across organisational and individual levels. This study therefore embarks on a multi-level investigation of hypocritical PEB at both organisational and individual (workplace context only) levels, based on a grounded theory approach. We aim to contribute to the hypocrisy, corporate social responsibility, and PEB literature streams by presenting a model of hypocritical PEB across levels. Drawing on 33 interviews with academic and administrative staff in the education sector, we identify legitimacy-seeking as a major driver of hypocritical PEB across levels. By critically examining the interconnectedness of organisational and employee levels, we identify two key social contextual factors potentially affecting the emergence of hypocritical PEB at the employee level: the locus of responsibility and employee-organisation alignment.
\end{abstract}

Keywords: Pro-environmental behaviour; Hypocrisy; Legitimacy-seeking; Multi-level analysis; Locus of responsibility; Alignment 


\section{Introduction}

Workplace pro-environmental behaviour (PEB) has sparked a new stream of research on hypocrisy. At the organisational level, PEB often manifests as greenwashing (Siano, Vollero, Conte, \& Amabile, 2017) and symbolic corporate environmentalism (Bowen, 2014), while at the individual level (i.e., workplace), it manifests as decoupling of corporate environmental management standards (e.g., ISO 14001) from routine work (i.e., employees ceremonially perform PEB during audits instead of rigorously complying with ISO standards in their work outside audit periods; Boiral, 2007). Such studies identify the existence of hypocritical PEB at the organisational and individual levels separately but do not explicitly define the term or conduct a systematic investigation of it across levels or in terms of their interconnectedness. Evidence of hypocritical PEB at the individual level within a workplace context is also scant.

Our study addresses these research gaps and builds a multi-level model of hypocritical PEB drivers, focusing specifically on the organisational and individual (workplace) levels, in response to criticisms on fragmented single-level frameworks (Aguinis \& Glavas, 2012) and the overlooked role of employees in the corporate greening process (Mirvis, 2012). ${ }^{1}$ Specifically, we aim to answer the following research questions: Do organisations and employees perform hypocritical PEB? If so, what drives hypocritical PEB across organisational and employee levels? How does the interconnectedness of organisational and employee levels affect the emergence of hypocritical PEB?

Guided by Bitektine and Haack's (2015) multi-level theory of legitimacy process, we employ a grounded theory approach to develop a systematic investigation of hypocritical PEB based on 33 semi-structured interviews with mid- and senior-level sustainability managers across multiple universities (for organisational-level analysis) and full-time employees within one university (for employee-level analysis). Our study (1) reduces the

\footnotetext{
${ }^{1}$ We use the term "employee level" to refer to the individual-level investigation within a workplace context.
} 
confusion caused by the fragmented PEB literature and offers an integrated multi-level analysis of hypocritical PEB, thereby contributing to the PEB and corporate social responsibility (CSR) literature streams; (2) delineates the difference between the constructs of substantive and hypocritical PEB; and (3) explains hypocritical PEB from a multi-level perspective by identifying legitimacy-seeking as a key motive applied across the two levels and the social contextual factors (i.e., locus of responsibility and employee-organisation alignment) underlying their interconnectedness. On that basis, we offer valuable practical insights to managing employees' hypocritical PEB.

\section{Literature review}

\subsection{Hypocritical versus substantive PEB}

We define "hypocritical PEB" as any claims or actions that appear to be ecologically friendly but are made or initiated primarily out of self-interest (i.e., for the benefit of the organisation or employee rather than primarily for doing good for the environment). We derive our definition from the merging of corporate hypocrisy (i.e., what one claims to be and what one truly is; Carrington, Neville, \& Whitwell, 2014; Wagner, Lutz, \& Weitz, 2009) and individual moral hypocrisy (i.e., a desire to appear moral in one's own and others' eyes while trying to avoid the associated costs of actually being moral; Batson, Thompson, Seuferling, Whitney, \& Strongman, 1999). Our definition applies to both corporate and individual levels and takes into account claims and actions that may entail hypocritical components.

Notably, not all PEB is hypocritical, even if PEB is grounded somewhat on self-interest. Human behaviour is the product of multiple forces, some conscious and some unconscious, as suggested in research on instrumental and symbolic motives behind consumption activities (Steg, 2005). Thus, across employee and organisational levels, PEB often results from "a mixture of self-interest (e.g., to pursue a strategy that minimises one's own health risk) and of concern for other people such as the next generation, other species, or whole ecosystems 
(e.g., preventing air pollution that may cause risks for others' health and/or the global climate)" (Bamberg \& Möser, 2007, p. 15). However, we argue that hypocritical PEB differs fundamentally from substantive PEB because it is based primarily on self-serving behaviour and less on a desire to do environmental good. By contrast, substantive PEB entails more active responses to eco-problems, and environmental sustainability is addressed substantively, strategically, and systematically instead of treated as an "add-on" (Whiteman, Walker, \& Perego, 2012). Moreover, substantive PEB generates a more positive impact on the environment than hypocritical PEB, as the latter is short of genuine interest in substantial progress on reducing environmental impacts (Steg \& Vlek, 2009). Thus, hypocritical PEB needs to be transformed into substantive PEB, given growing concerns about environmental degradation and increased environmental exploitation and pollution (Davies, Fahy, \& Rau, 2014).

To better establish the difference between substantive and hypocritical PEB, consider, for example, a daily activity, such as car usage, that despite its usefulness also has negative impacts on the quality of the environment and, thus, the quality of life. According to Steg (2005, p. 149), car usage "may have an instrumental function (i.e., it enables activities)" and "a symbolic function (i.e., the car is a means to express yourself or your social position)". In applying this definition to PEB across levels, instrumental functions would be about doing good to the environment for the benefit of oneself, society, and future generations, essentially enabling a better quality of life for oneself and others. Symbolic functions would refer to what PEB signals about the person or organisation espousing such behaviour-in other words, what PEB symbolises or indicates about the person or organisation and the group membership to which such behaviour gives them access. Table 1 shows how substantive and hypocritical PEB differ across levels depending on three key factors: self-interest, environmental concerns, and symbolic functions. 
--- Insert TABLE 1 about here---

\subsection{Organisational and individual hypocrisy towards $P E B$}

Organisational hypocrisy is visible to outsiders when inconsistency among an organisation's talk, decisions, and actions occurs (Greenbaum, Mawritz, \& Piccolo, 2015). With the aim to balance the conflicting needs of heterogeneous stakeholders (Cho, Laine, Roberts, \& Rodrigue, 2015), organisational hypocrisy is widespread and reflects the turbulent environment in which organisations operate (Brunsson, 2002). Organisational hypocrisy can be damaging for business and society as it may intensify the gaps between commitments and resources, undermine reforms, or fail to protect society from externalities (Lipson, 2007). It can also undermine consumers' positive attitudes towards a firm (Wagner et al., 2009) or a brand (Sweetin, Knowles, Summey, \& McQueen, 2013). However, organised hypocrisy may also allow organisations "to manage irreconcilable pressures that might otherwise render them incapable of effective action and threaten [their] survival" (Lipson, 2007, p. 5). For example, the United Nations decouples its talk and action to authorise behaviours of contradictory parties for the success of peace operations (Lipson, 2007). Overall, themes on organisational hypocrisy examined in prior research include organised hypocrisy (Brunsson, 2002), the gap between sustainability discourse and practice (Cho et al., 2015), hypocrisy in branding management (Kim, Hur, \& Yeo, 2015), and hypocrisy in integrated marketing communication practices for delivering positive CSR messages (Jahdi \& Acikdilli, 2009).

Individuals exhibit moral hypocrisy when morality is highly extolled on purpose in an effort to serve their self-interests (Campbell, 1975). Built on the idea of reciprocal altruism (Trivers, 1971), the reasons for being a moral hypocrite are to garner self and/or social rewards and to avoid punishments (Batson et al., 1999). Often, moral hypocrisy can be operationalised as moral weakness, whereby individuals fail to uphold moral values and standards (Thomas, DeScioli, Haque, \& Pinker, 2014). Factors underpinning individual moral 
hypocrisy include a desire to signal generosity (Ellingsen \& Johannesson, 2011), generate good and alleviate bad feelings (Aknin et al., 2013; Andreoni, 1989), anticipate social rewards (e.g., prestige, reputation, wealth, status), avoid social punishments (Griskevicius, Tybur, \& Van den Bergh, 2010), and comply with social pressures (DellaVigna, List, \& Malmendier, 2012). Overall, prior studies on individual moral hypocrisy have examined the various types of moral hypocrisy (Graham, Meindl, Koleva, Iyer, \& Johnson, 2015), impure altruism (Leygue, Ferguson, \& Spence, 2017), reciprocal altruism (Trivers, 1971), and reluctant altruism (Reyniers \& Richa, 2013), among other factors.

Given our study's focus, evidence shows that both organisational- and employee-level PEB can interact with and influence each other. For example, greenwashing, which is a manifestation of hypocritical PEB, covers negative environmental performance and involves participation of both the organisation and its employees (Siano et al., 2017). Consider the Volkswagen emission scandal. The company originally received green car subsidies and tax exemption in the US for its low-emission vehicles (Dans, 2015) but ended up being charged with systematically cheating emissions tests through a "defeat device" (Hotten, 2015). At the same time, six senior Volkswagen employees from Germany, including the emissions compliance manager, Oliver Schmidt, were prosecuted for fraud, and more than 40 employees allegedly participated in the company's elaborate cheating scheme (Agerholm \& Agencies, 2017). The Volkswagen case represents a real-life example of the interconnectedness of organisational- and employee-level hypocritical PEB.

\subsection{Drivers of hypocritical PEB at organisational and employee levels}

Organisational PEB contains both symbolic and substantive components, though in extreme cases it can be purely symbolic (Bowen, 2014). The conventional view of organisational PEB stresses the economic and social benefits of acquiring social reputation and legitimacy, which is consistent with three motives suggested by management theories: (1) the legitimation 
motive (Bansal \& Roth, 2000), which draws on the institutional theory (Scott, 2014); (2) the stakeholder pressure motive (Kassinis \& Vafeas, 2006), which draws on stakeholder theory (Clarkson, 1995); and (3) the competitiveness motive (Bansal \& Roth, 2000), which draws on the resource-based view of the firm (Hart, 1995). The critical view emphasises that organisations may superficially engage in corporate environmentalism to signal their status and authority in exchange for privileges (Banerjee, 2012).

At the employee level, under moral hypocrisy reasoning (Batson et al., 1999), actors of PEB want to appear morally justified (i.e., being green) without paying the cost of personal sacrifice inherent in being ecologically responsible or pretending to pay the cost. Often, PEB engagement is merely about striking a balance between normative self-interest (the culturally legitimate motivation to behave in one's own best interests; Ratner \& Miller, 2001) and selfishness (socially unacceptable behavioural standards that put one's own needs/interests/desires ahead of those of others; Hastings, Zahn-Waxler, \& McShane, 2006). Employee PEB may stem from a desire to comply with organisational environmental policies (Norton, Zacher, \& Ashkanasy, 2014) and social norms (Blok, Wesselink, Studynka, \& Kemp, 2015), particularly when employees are in a high-conformity setting for identity control (Alvesson \& Willmott, 2002), or to improve the organisation's reputation (Leygue et al., 2017). Drawing on the idea of impure altruism (Andreoni, 1989), we also argue that motivations of PEB include emotional rewards and a desire to avoid the shame of not behaving altruistically (Ferguson, 2015). Yet, to our knowledge, no research has specifically examined hypocritical PEB at the employee level.

\subsection{A multi-level theory of the legitimacy process}

Legitimacy is underpinned by "a generalized perception or assumption that organisational activities are desirable, proper, or appropriate within some socially constructed system of norms, values, beliefs, and definitions" (Suchman, 1995, p. 577). Legitimacy theory posits 
that organisations proactively or reactively ensure that they operate within the boundaries established in an institutional environment (Scott, 2014). Applying this theory to corporate social and environmental disclosures (Deegan, Rankin, \& Tobin, 2002), previous research indicates that organisations may signal conformity to norms, stakeholder pressures, and regulations through hypocritical PEB to appear as legitimate businesses (e.g. Ashforth \& Gibbs, 2008). Assessing the micro-level, psychological, and socio-cognitive aspects of institutions (Berger \& Luckmann, 1971), Bitektine and Haack (2015) develop a multi-level theory of the legitimacy process, emphasising that legitimacy is a collective perception comprising subjective judgements of "what is legitimate" for employees but aggregated and objectified at the collective level. Legitimacy is thus "a judgment, with respect to that organization, rendered by employees at the micro level and by collective actors at the macro level" (Bitektine \& Haack, 2015, p. 50). As such, legitimacy can be mutually shaped by organisations and employees in a top-down or bottom-up fashion. Organisational behaviours are motivated to gain legitimacy regulated by both parties (i.e., organisation and employee).

Legitimacy-seeking also occurs at the employee level. Individuals often attempt "to regulate their self-esteem" through "ego-defense mechanisms" such as legitimacy-seeking and may have a level of healthy (or unhealthy) narcissism (Brown, 1997, p. 643). Brown further (1997, p. 664) notes that "[t]he idea that the self-esteem of individuals is regulated partly through their participation in groups and organizations throws new light on the dynamics by which collectivities gain and maintain internal legitimacy". Such behavior helps not only legitimise employees and preserve their self-esteem but also legitimise the groups these employees want to be a part of. In other words, legitimacy-seeking behaviour between employees and groups is reciprocal and beneficial for both. Therefore, in line with the notion of legitimacy, employees would depict their workplace behaviours as appropriate, proper, and desirable within an established set of organisational values, norms, and rules to legitimise 
themselves. This process then leads to identification with the group/organisation, which in turn improves self-esteem, in line with social identification theory (Ashforth \& Mael, 1989). In addition, research investigating the drivers of employee PEB in the workplace echoes the kind of legitimacy-seeking behaviour that occurs at the organisational level (e.g., employees perform PEB to conform with norms, values, and sustainable policies based on the external environment) (Norton et al., 2014). Given that legitimacy-seeking can motivate both organisational and employee behaviours, we base our multi-level exploration of hypocritical PEB on the multi-level theory of legitimacy to examine hypocritical PEB across levels.

\section{Methodology}

We carried out 33 semi-structured, in-depth interviews in the higher education sector in line with our research aims to explore organisational- and employee-level hypocritical PEB. Universities served as our sampling context, as they receive institutional attention and are under pressure by a diverse range of stakeholders to increasingly promote environmental sustainability (Muijenheidi, 2004). Of the 33 interviews, 14 were with 15 sustainability directors/managers (two participated in an interview together) based in 13 different UK universities listed in the People \& Planet University League (2016). This league ranks universities on their environmental performance and provides information on their environmental policies, strategies, programmes, number of staff in the sustainability department/team, and other publicly available information. To ensure the triangulation and transferability of data (Creswell \& Poth, 2017), we aimed to capture diverse viewpoints about universities' $\mathrm{PEB}$ by selecting those active in terms of environmental performance, but at different degrees. Sustainability managers (or directors) are responsible for universities' environmental-related decisions and activities and thus have a good understanding of universities' behaviour toward and motivation for PEB (Ramirez, 2013). The remaining 19 interviews were with full-time employees (i.e., academics and professional service members) 
of a large university (anonymised as university X) located in the southeast UK. Before data collection, we obtained ethical approval and informed consent, with assurances of participant anonymity (see the online supplementary material for all profiles).

At the organisational level, we used semi-structured interviews to collect rich data (Drever, 1995), with the goal to explore organisational behaviours based on managers' viewpoints. Semi-structured interviews allow verbal interchange between the interviewer and informant, thus offering more flexibility and depth in eliciting information beyond "yes/no" answers (Drever, 1995). During the interviews, sustainability managers mainly addressed their department/team and universities' environmental statements, strategies, programmes, initiatives, and performance. We also asked them to explain the reasons behind universities' environmental sustainability endeavours, the outcomes of these endeavours, and any challenges encountered while implementing green initiatives (see the online supplementary material for a detailed interview schedule).

At the employee level, we used an adapted critical incident interview technique (Flanagan, 1954), with the goal to explore employee behaviours at work. This technique allowed us to collect observations as "incidents", depending on their specific importance and relevance to targeted behaviours (i.e. workplace PEB), and to examine events across levels (Butterfield, Borgen, Amundson, \& Maglio, 2005). Employees described their job role, work routines, and awareness and familiarity of any existing green initiatives at university $\mathrm{X}$. They were then prompted to think of a recent workplace PEB (e.g., recycling, printing reduction, switching off PC/lights) and asked a series of questions about the action, in line with the critical incident interview technique.

Interviews across the two levels lasted between 20 and 55 minutes and were conducted over a six-month period by the first author. Data collection ended when the interviews reached theoretical saturation. We anonymised informants' details to safeguard 
confidentiality and use coded names herein (e.g., SI01 indicates informant 01 of the sustainability managers interviewed at the organisational level; XI01 indicates informant 01 from university X at the employee level). We employed Glaser and Strauss's (1967) grounded theory method for data analysis, which involved separating the collected data and comparing them within and across levels. The process involved carrying out systematic and detailed data coding. Through several rounds of data analyses with the help of NVivo 12 software, we sorted the data in new categories of meaning. We used thematic coding for indexing text or ideas and drawing examples from the data to "establish a framework of thematic ideas" (Gibbs, 2008, p. 38). The coding process was directed by the Gioia methodology (Gioia, Corley, \& Hamilton, 2013). Here, we clustered a list of first-order concepts corresponding to PEB motives and the interconnectedness of the two informant levels into second-order themes and then aggregated them into three overarching themes (Table 2). New constructs helped us explain how the employee and organisational levels are interconnected with PEB. Specifically, in addition to legitimacy-seeking, we found that locus of responsibility and employee-organisation alignment are critical factors determining the link between employee- and organisational-level (hypocritical) PEB.

--- Insert TABLE 2 about here---

The Gioia method 'brings 'qualitative rigor' to the conduct and presentation of inductive research" (Gioia et al., 2013, p. 15). Specifically, the method fits well with the employed grounded theory approach, due to two reasons: (1) its research design includes "how" questions and "surfacing concepts and their inter-relationships" (Gioia et al., 2013, p. 26), which matches our research aim, and (2) it allows unveiling dynamic relationships in the data and serves as the basis for further engagement with the literature to articulate emerging concepts (i.e., locus of responsibility and employee-organisation alignment) and relationships (i.e., employee- and organisational-level interconnectedness). For example, 
"control air pollution demanded by the Clean Air Act" is a first-order category emerging from our data that corresponds to "legal compliance" as a second-order theme, which then relates to the aggregate dimension of legitimacy-seeking (Table 2).

\section{Findings}

In the interviews, we wanted to explore PEB and how it is understood and shaped by both employees and organisations. However, during the interviews, we found that hypocritical behaviour was a prominent, recurring theme, though not all behaviour was hypocritical PEB. We first present the evidence on hypocritical PEB at the employee and organisational level and then discuss why employees and organisations engage in hypocritical PEB. In general, at the employee level, sustainability managers suggested that universities performed hypocritical PEB for three main reasons: (1) to comply with legal requirements, (2) to cope with institutional forces, and (3) to benefit themselves. At the organisational level, employees at university $\mathrm{X}$ indicated that they engaged in hypocritical PEB for three major reasons: (1) to comply with workplace initiative, (2) to comply with external rules and norms, and (3) to save costs. In addition, we discuss two emerging themes from our data related to the interconnectedness of the two levels, to further extend the theory on PEB and hypocritical PEB in particular: locus of responsibility and employee-organisation alignment. We define "locus of responsibility" as the attribution of responsibility to different parties that clarifies issues such as "who should be doing more for what" and "what are positive and negative outcomes of an act" (Brewin \& Shapiro, 1984) and "employee-organisation alignment" as the alignment of actions and interests between employee behaviours and organisational strategy (Colvin \& Boswell, 2007).

\subsection{Existence of hypocritical PEB at both organisational and employee levels}

Social desirability bias (Dermody, Koenig-Lewis, Zhao, \& Hanmer-Lloyd, 2017; Fisher, 1993) leads respondents to answer questions in a manner that they perceive will be evaluated 
as favourable, likeable, and ethical by others. Hypocritical PEB is generally considered socially undesirable given its focus on self-interest. Thus, capturing true thoughts on hypocritical PEB can be difficult when directly asking people about it. The concept of selfdeception (Mele, 2001) also suggests that individuals are able to "behave self-interestedly while ... falsely believing that one's moral principles were upheld" (Tenbrunsel \& Messick, 2004, p. 223). Therefore, to reduce social desirability bias, we employed a strategy of indirect questioning (Fisher, 1993) and did not explicitly ask respondents whether they or their organisations engaged in hypocritical PEB. We identified substantive versus hypocritical PEB by using the functions in Table 1 (i.e., self-interest, environmental concern, and symbolic) consistent with our definitions. Informants occasionally noted that they engaged in PEB for self-serving reasons rather than environmental concern. We also probed for hypocritical PEB indirectly when informants stated reasons that explained their behaviour as containing symbolic meaning, such as "show" compliance to rules, thus signifying potential hypocritical behaviour. Table 3 provides both organisational- and employee-level examples that showcase hypocritical and substantive PEB as identified from our data.

\section{---Insert TABLE 3 about here---}

At the organisational level of analysis, sustainability managers explicitly revealed the existence of hypocritical PEB. The pursuit of funding from the Higher Education Funding Council for England (HEFCE) $)^{2}$ was the most frequently mentioned reason for universities to engage in PEB. Another major reason is cost reduction; for example, SI11 noted that "the main reason that the sustainability team exists is to save university money". At the employee level of analysis, no employee explicitly stated a self-serving purpose as the primary reason for PEB. Most employees claimed a felt responsibility to perform PEB because it is the right thing to do. However, employee-level hypocritical PEB surfaced when informants described

\footnotetext{
${ }^{2}$ HEFCE closed in April 2018.
} 
the reasons for engaging in PEB with regard to the benefits around their job or the university. For example, as XI10 said about recycling:

One is all about saving money for the university, for the students, basically... Our aim is to give the best service to the students so that they can be successful in doing their degree. And so we have to spend that money appropriately, all right? And spending it on paper across the university is an expensive thing ... because the less we spend, the more we can spend in other areas to improve the student experience. So that is our aim, it's all about the student experience.

Another form of hypocrisy involving PEB at the employee level was PEB disengagement; here, employees' behaviour might be hypocritical but not necessarily hypocritical PEB. Some informants claimed that while they know they are supposed to engage in PEB, their selfinterest (e.g., laziness) prevails at the expense of any environmental concern. A typical example is the failure to sort garbage at the workplace:

There used to be a big pink bag that was under our desk, because I share a desk with somebody else, and that would be for recycling and for some reason it just disappeared one day, a couple of weeks ago. But I should ask why because I used it every day, and it's really bad ... it's laziness so I should just do it, I should. (XI07)

Another example of hypocritical behaviour is the silence towards wrongdoing observed at the workplace. Informant XI04 said: "So they [colleagues] will [...] put on their heating and then they'll leave it. So it's heating nobody and it's just wasting energy". When asked about his reaction to this energy waste at the workplace, he said, "I usually don't engage in discussion or argument about it because ... I choose my battles.... It's senior members of staff. So it's older people and more senior and I don't want to upset them”. Picking one's battles despite wanting to voice objection to others' behaviour reflects hypocritical behaviour that is removed from any environmental concern. In other words, as these two examples show, while the context may be environmentally related, not all hypocritical behaviour is PEB related.

\subsection{Organisational-level factors for hypocritical PEB}


In this sub-section, we present findings showing various reasons that universities perform PEB, though none reflect a clear focus on reducing negative environmental externalities. Thus, most organisational-level PEB is hypocritical PEB. The pursuit of HEFCE funding, cost reduction, good public relations (PR), and student recruitment are the focal points of managerial efforts and the underlying reasons for organisational-level hypocritical PEB.

\subsubsection{Legal compliance}

As many sustainability directors/managers noted, universities have legal requirements to deliver environmental sustainability set by the local government, the Clean Air Act, and the Planet Commission. Some managers claimed that universities have no choice but to comply with government requirements or risk breaking the law. Thus, universities adopted ISO 14001 (ISO, 2018) or other carbon management plans so as to signal legal compliance and that they are an environmentally caring organisation (SI02, SI08). An ISO 14001 credential is a public recognition of environmental sustainability:

The benefit is to gain an internationally recognised certification level.... [It is the] same difference between "you can drive a car" and "you have a driving license". It is possible [to] drive a car without a driving license... but if you tell somebody you have a driving license, then everybody knows you can drive a car. (SI13)

\subsubsection{Institutional forces}

Managers disclosed that universities are under pressure to meet carbon reduction targets set by the HEFCE. A carbon management plan or an ISO 14001 environmental management system helps obtain HEFCE funding. Some informants also mentioned pressures from staff, students, or the broader community for universities to provide leadership in sustainability (SI03, SI09) and "act as an agent for change" (SI03). These forces drive universities to adopt environmental sustainability practices to meet different stakeholders' expectations.

\subsubsection{Benefits}

Many sustainability managers described PEB as a way to receive capital funds from HEFCE.

They claimed that environmental sustainability is an incentive to help ensure campus growth 
and improvement. On the one hand, being energy efficient "makes good business sense" from "a cost-saving point of view" (SI10, SI02). As SI11 noted: "the main reason that the sustainability team exists is to save university money"; “if we weren't saving money, I don't think that the university would be that bothered". The costs for the university come not only from consumption bills but also from purchasing carbon allowances as one of the larger users of energy, as required by the CRC Energy Efficiency Scheme (CRC Energy Efficiency Scheme, 2014). On the other hand, environmental sustainability can be a selling point for attracting future students; "it is very much like a kind of PR, it's good PR for the university" (SI02).

These findings imply that universities primarily engage in PEB for their own benefits - to display organisational conformity to legislations and institutional forces so as to be appreciated and not penalised, to accumulate capital resources for campus growth and development, or to attract future students. Organisational-level hypocritical (vs. substantive) PEB was evident, with the hidden agenda behind environmental sustainability mainly revealing self-interest rather than a desire to reduce negative environmental impacts. The first two motivational factors-namely, legal compliance and institutional forces-reflect the need for organisations to undertake appropriate and proper practices that help legitimise their business activities in the eyes of outsiders. The third motivational factor (i.e., benefits) corresponds to an intention to engage in practices that make business sense. Overall, organisational-level hypocritical PEB was considered appropriate, proper, and desirable within established institutional values, norms, rules, and laws of legitimacy.

\subsection{Employee-level factors for hypocritical PEB}

In this sub-section, we elaborate on various motivational factors related to employee hypocritical PEB, including cases in which employees' reasons for engaging in PEB were irrelevant to any genuine environmental concerns. Specifically, three motivational factors 
were compliance to workplace initiative, compliance to external rules and norms, and cost reduction for the university.

\subsubsection{Compliance to workplace initiative}

Informants frequently mentioned a campus-wide green initiative as driving and guiding employees' PEB at university $\mathrm{X}$. Green ambassadors across the university serve as representatives in delivering green messages, promoting green initiatives, reviewing group activities, and reporting back to the sustainability team. As part of the university's accreditation scheme, the central sustainability team evaluates departments' environmental performance and grants Gold, Silver, or Bronze awards on a competitive basis. These awards represent green performance at the team or departmental level. Thus, performing hypocritical PEB is way for employees to cope with collective pressures and requirements set by the central sustainability team. For example:

So if I was to leave work and I accidentally left my computer screen on, [I] would, maybe, be getting an email saying, "Noticed your computer was left on last night." Or something like that. (XI08)

\subsubsection{Compliance to external rules and norms}

Some employees reported the need to comply with the organisation's rules on performing PEB. For example, XI16 said:

We have quite a strict rule on the aircon usage as well. We've only used it one day for this year and we're not allowed to turn it up to a certain level,... something like it can't go below 22 [-degrees centigrade].

Social norms are critical in motivating hypocritical PEB, particularly if the behaviour is perceived as effortless and normative. As XI01 noted:

We're just expected to do it.... Everything is set up for us, there's no reason why we shouldn't recycle.

Informant XI09 suggested that employees tend to "follow suit" in terms of others" recycling behaviours, and XI08 specifically noted the importance of obtaining others' approval by engaging in environmentally friendly behaviour. In addition, some informants described PEB 
as stereotypical behaviour, influenced by the "culture of veganism" (XI04). This reflects the effect of social categorisation, group norms, and expectations on employee behaviour (Hogg \& Reid, 2006). As XI07 explained:

It can be very stereotypical context, you know, if you're a loving hippie that likes gardening and you've got compost bins, and you don't wear anything that [has] come from animals and things like that, yeah, I think it ... can definitely have a sort of stereotype that's attached to being an environmentally friendly person.

As these comments show, a major reason employees engage in hypocritical PEB is to comply with (formal and informal) rules and norms, through which their behaviours are legitimised in such a social context.

\subsubsection{Cost-saving for the university}

Organisational identification encourages employees to often view their own PEB as a way to reduce costs for the university. For example, XI08 said:

Not everybody wants to do that [recycling]. But if I didn't, I guess the university would have to pay more costs for waste disposal. That's the main [reason] really and obviously there'd be more waste in landfill.

We also sensed a pursuit of indirect personal benefits in terms of job roles. As many informants claimed, less costs mean more resources to enhance student experiences at university $\mathrm{X}$, which is consistent with their job aims.

Our findings also illustrate that certain employees show an intent to comply with the workplace initiatives, rules, and norms or to save costs for university $\mathrm{X}$ by engaging in PEB. With such primary objectives, their personal interest in minimising any negative impact on the environment appears to fade. Indeed, showing conformity to external constraints helps employees legitimise their own behaviour at work. Cutting costs demonstrates their desire to act in a way that is viewed as satisfying and fulfilling in terms of their job roles. Thus, many employees deem hypocritical PEB as appropriate, proper, and desirable within the established system of values, rules, and norms in a specific social context (the workplace), as they seek internal (i.e., within the organisation) legitimacy with a view to enhance their self-esteem. 


\subsection{Interconnectedness of organisational and employee levels}

Themes about the interconnectedness of two levels also surfaced. Our findings suggest that interconnectedness affects the occurrence of employee-level hypocritical PEB. Two themes regarding the interconnectedness of the two levels include locus of responsibility and employee-organisation alignment.

\subsubsection{Locus of responsibility}

We observed tension in our data between the organisation's and employees' expectations of the attribution of responsibility or, in other words, where the locus of responsibility lies (i.e., who should be more actively promoting environmental sustainability). While university $\mathrm{X}$ decentralises its responsibilities by relying on employee PEB engagement, employees expect more actions from the top. As sustainability managers representing university $\mathrm{X}$ emphasised, staff and student PEB is critical to achieve environmental sustainability; however, employee PEB engagement is challenging:

There are lot of other events, there are a lot of other people that are trying to kind of push their own agendas or engage people in other variety of things. I suppose, that's one of our challenges is actually getting the voice heard, making people realise that it's important, and encouraging them to engage with us. (SI09)

Employee informants at university $\mathrm{X}$ disclosed a paradox between organisational communications and actions, because environmental sustainability never seemed as important as it was claimed to be. For example, XI09 expressed cynicism about environmental sustainability being a low organisational priority:

If you tell maintenance "someone might die or be seriously injured", even then they might ignore it, but they might do something. But if it's like an environmental issue, it doesn't appear to be a priority.

Similarly, employees stated that PEB also has low priority on their work agendas, and personal consequences regarding PEB engagement or disengagement are absent, due to a lack of organisational proactiveness on environmental sustainability issues. There was an overall 
sense that leadership should be driving green initiatives, that "there needs to be some messages from the top people saying, 'we'd like you to recycle a bit more"' (XI03).

The consequences of a lack of explicit distribution of responsibilities are twofold. First, employees regard PEB as an add-on, separate from daily routines, and as a result they are demotivated to engage in it, despite personally perceiving environmental sustainability as important. For example, XI09 said:

People are more interested in doing their own jobs ... sustainability, health, and safety, they're really important but people do view them as extra,... [and] that's when they have the choice not to do it.

Second, employees who disengaged from PEB believed that university $\mathrm{X}$ would instead take care of things related to PEB:

In the evening, if we leave the light on, somebody will come and switch it off ... it will be somebody maybe you know, the guard.... [In] my mind there's somebody trying to check [the] entire building and ... switch off the lights, and do something with the garbage or something like this. (XI06)

\subsubsection{Employee-organisation alignment}

We also observed a shared agreement of values towards PEB and of organisational/job goal priority in our data. This employee-organisation alignment reflects the extent to which employees identify and agree with the organisation's PEB-related values (or lack thereof). The majority of employee informants at university $\mathrm{X}$ noted that PEB is the right thing to do (indicating value alignment), but also that it has low organisational/job priority in practice (indicating goal alignment). However, some informants demonstrated a relatively high goal priority of PEB because their job roles are associated with PEB. For example, XI07, who is responsible for student experience and support, mentioned how saving university resources through PEB contributes to enhanced student experiences, and XI09, who is in charge of administrative expenditures, mentioned that saving stationery resources is part of his job role. However, goal alignment might discourage employees from PEB because most of the time, the organisation does not value it. 


\section{Discussion and conclusion}

PEB is a mixture of self-interests and environmental concerns (Bamberg \& Möser, 2007) and is enacted in the workplace at both the employee and organisational levels. To explore this complexity, we conducted an exploratory multi-level analysis of hypocrisy within the context of PEB using in-depth interviews. Our research questions aimed to explore whether organisations and employees perform hypocritical PEB and what drives hypocritical PEB across organisational and employee levels. In addition, we explored the interconnectedness of two levels of PEB and their impact on hypocritical PEB.

Our findings show that organisations and employees engage in hypocritical PEB and that legitimacy-seeking is a shared driver of hypocritical PEB. We also found two key factors that can affect the emergence of hypocritical PEB at the employee level: locus of responsibility and employee-organisation alignment. Our multi-level model of hypocritical PEB presented in Fig. 1 captures our observations. We find that both levels have a set of drivers that define their legitimacy-seeking behaviour (e.g., legal compliance at the organisational level and cost-saving practices at the employee level). We also find that where responsibility lies (i.e., locus of responsibility) and the extent to which this is organisation-driven (e.g., the organisation puts responsibility of engagement on the employee) or employee-driven (e.g., employees want to proactively engage in PEB) have an impact on the extent to which PEB is taken seriously or not (see the dashed arrows in Fig. 1 within the locus of responsibility domain). We also find that the locus of responsibility and legitimacy-seeking behaviour whether at the employee or the organisational level - are interrelated (see solid double-edged black arrows in Fig. 1). When the locus of responsibility lies at the organisation level (i.e., the organisation expects its members to engage in PEB), employees will seek internal legitimacy (Brown, 1997) by engaging in PEB, whether they believe in it or not, which leads to hypocritical PEB. Conversely, when the locus of responsibility lies at the employee level (i.e., 
it is at employees' discretion to engage in PEB), employees' legitimacy-seeking behaviour will be driven by how they want to be perceived by their colleagues rather than whether they meet the organisation's rules and expectations.

We consequently unpack what our findings suggest about organisational and employee PEB - hypocritical or not. First, many sustainability managers suggested that PEB was primarily to ensure that organisational activities were legally compliant and desirable (e.g., save costs, good PR) in response to external forces and expectations and in accordance with legitimacy theory applied to corporate ecological responsiveness (Bansal \& Roth, 2000; Cho et al., 2015). Our findings are consistent with the conventional view of corporate environmentalism that stresses the economic and social benefits of acquiring social legitimacy through corporate greening (Bowen, 2014) as well as prior empirical findings confirming financial returns from CSR (Barnett, 2007). Although universities need to make their environmental-related activities visible and accessible to both internal and external stakeholders to be recognised as legitimate (Maigan, Ferrell, \& Hult, 1999), in our study they seem to adopt a proactive communication strategy in which they "disseminate specific information to create an image of social responsibility before any potentially negative behavioural CSR information is received" (Wagner et al., 2009, p. 79). However, this can be far from risk free: if discovered, under-performance in environmental sustainability can have lasting negative impacts, overshadowing everything else (Highhouse \& Gallo, 1997). We suggest that an organisation should not only strategically coordinate different communication tools to deliver clarity and consistency in its messages (Porcu, Del Barrio-García, \& Kitchen, 2017) but also avoid the self-promoter's paradox, in which they overly communicate CSR (including PEB) and, as a result, hurt their credibility (Morsing \& Schultz, 2006).

Second, we recognise that some employee-level PEB is primarily self-serving behaviour, mainly employed to display conformity with workplace initiatives, rules, and social norms, to 
satisfy a job role, or to save costs for university X. An integration of the personal self and social identity (i.e., perceived membership in the organisation) came into play when employees answered questions on job roles instead of other roles (Amiot, De La Sablonnire, Terry, \& Smith, 2007). Organisational identification, defined as "perceived oneness with an organization and the experience of the organization's successes and failures as one's own" (Mael \& Ashforth, 1992, p. 103), was visible in employees' responses in our study. Employees' responses in the interviews often pertained to serving the job or university $\mathrm{X}$ rather than the self. For example, for some respondents, less costs meant more resources to increase student experiences, which is consistent with their job aims. Leygue et al. (2017) report similar results from employees working in for-profit organisations, who were motivated to save electricity at work so as to indirectly receive benefits from an improved organisational status, including reputation and resources.

Based on Brown's (1997) theory on identity and legitimacy, hypocritical PEB materialises employees' internal legitimacy when they behave in an appropriate, proper, and desirable manner within a social context (i.e., workplace), which in turn enhances their selfesteem. Along with our previous discussion on organisation-level hypocritical PEB, our study suggests that both macro- and micro-level hypocritical PEB are initiated by legitimacyseeking, in support of Bitektine and Haack's (2015) multi-level theory of the legitimacy process. Relatedly, we find that not all hypocritical behaviour is hypocritical PEB. For example, employee informants indicated not recycling if the recycling bin was not placed next to them. This "laziness" implies a hedonic goal frame behind behaviour (i.e., the pursuit of personal pleasure), by compromising a normative goal that would involve engaging in PEB (Lindenberg \& Steg, 2007). Such actions are independent of any PEB context but are hypocritical nonetheless. 
Third, our study conceptualises two key factors underlying the interconnectedness of the organisational and employee levels that can lead to hypocritical PEB at the employee level: locus of responsibility and employee-organisation alignment. According to employee informants at university $\mathrm{X}$, they faced neither positive nor negative detriment to themselves whether they performed PEB or not and despite the organisation's emphasis on employee engagement with green initiatives. Instead, employees tended to expect the organisation to act on and lead environmental sustainability, reflecting the importance of leadership on and organisational support for PEB (Robertson \& Barling, 2013). This finding implies a mismatch between employee- and organisational-level expectations in terms of "who" should be doing more regarding the promotion and implementation of green initiatives. An absence of locus of responsibility not only does not stop hypocritical PEB or turn it into substantive PEB but actually reinforces PEB inaction altogether because of employee indifference. As previously discussed, PEB-related hypocritical behaviour is prevalent at the employee level. Considering the individual determinants of behavioural change, the locus of responsibility is consistent with norm activation theory (Schwartz, 1977) and the value-belief-norm model (Stern, Dietz, Abel, Guagnano, \& Kalof, 1999), according to which personal responsibility is a determining factor of intentions to conduct PEB. We thus suggest that hypocritical PEB is to some extent better than a lack of PEB and that hypocritical PEB can turn into substantive PEB in the long run through habituation, at least at the employee level (Gregory \& Leo, 2003). Organisations should make an effort to communicate PEB in a clear way so that employees view PEB engagement as important. In particular, to eliminate PEB-related hypocritical behaviour, organisations can make employees' PEB accountable, such as by formalising authentic programmes and setting financial or social goals for environmental performance (Mcshane \& Cunningham, 2012). 
Under the locus of responsibility notion, the tension over formalisation of environmental sustainability may facilitate employees' hypocritical PEB if volunteerism is somehow mandated by the organisation (Mirvis, 2012). As our findings indicate, several employee informants already demonstrate a strong intent to comply with external forces through hypocritical PEB. A formalisation of distributed responsibility might strengthen the economic branch of social exchange between the organisation and the employee (Emerson, 1976), making PEB programmatic and a part of careerism (i.e. "propensity to achieve ... personal and career goals through non-performance-based activities"; Chiaburu, Muñoz, \& Gardner, 2013, p. 473). Locus of responsibility can even serve as negotiated reciprocity between the employee and the employer (Deckop, Cirka, \& Andersson, 2003). Thus, clarification of the locus of responsibility can be challenging for organisations because though it can reduce PEB-related hypocritical behaviour as a form of PEB inaction, it may also potentially encourage hypocritical PEB. However, we maintain that hypocritical PEB is a transitional phase to substantive PEB through the cultivation of habits.

With regard to employee-organisation alignment, with an alignment of values, both the sustainability managers and the employees at university X considered PEB important and appropriate to undertake, but for reasons that are primarily self-benefiting. For example, as mentioned previously, universities engage in PEB because doing so provides access to funding or establishes good PR. Similarly, employees agree that PEB is the right thing to do simply because it is required or expected by external rules and norms. More important, value alignment further intensified the multi-level legitimacy process formed by both parties, such that legitimacy-seeking extensively permeates their practices and behaviours. However, goal alignment paradoxically allows them to ignore environmental sustainability in daily practices, rendering them decoupled from environmental policies or guidelines. Specifically, employee informants viewed PEB as an extra-role behaviour (Vigoda-Gadot, 2007) that has low 
priority in their work agendas. This might imply a perception of treating green initiatives mostly as "window-dressing" (Collier \& Esteban, 2007), indicating poor communication of organisational goals to employees about the importance of environmental sustainability to the organisation (Arvidsson, 2010), or a rational myth of environmental sustainability on the organisational side (Boiral, 2007). Beyond the traditional view of encouraging micro-CSR engagement (including PEB) through the simple alignment of values/goals between the organisation and the employee (Mcshane \& Cunningham, 2012), our findings illustrate that alignment may exacerbate the emergence of employee hypocritical PEB because of the superficial promotion of environmental sustainability by the organisation.

As a possible solution, we propose integration of the locus of responsibility and employee-organisation alignment. When appropriately applied, both can inhibit the occurrence of employee hypocritical PEB when the organisation possesses environmental values (Akaah \& Lund, 1994) and substantially promotes greening practices. According to CSR culture literature (Duarte, 2010), this integration could help embed environmental sustainability into a company's culture (Swanson, 2014); in other words, it can enhance a CSR culture sustained by both the organisation and its employees. Duarte (2010, p. 358) defines CSR culture as "a set of more or less shared meanings, underpinned by the notion of sustainability, which endow an organisation with its distinctive character of being ethical, equitable and transparent in relation to social groups and the environment". The alignment of organisational and personal values creates a good person-organisation fit (Kristof, 1996) that contributes to a shared understanding of the CSR culture, in which environmental sustainability is systematically addressed through value-driven (vs. financially driven) policies or actions, thus helping to inhibit the negative side effects of locus of responsibility (Hancock, 2005). From the perspective of employee commitment (Brammer, Millington, \& Rayton, 2007), employees might be more enthusiastic to take on the responsibility of 
implementing green practices at work (Shore \& Wayne, 1993) if they commit to their organisation and share a similar viewpoint in terms of generating social, environmental, and economic capital (Collier \& Esteban, 2007). Employee-organisation alignment can reinforce employee commitment (Valentine, Godkin, \& Lucero, 2002), thus more clearly establishing the locus of responsibility.

In general, an integration of the two mechanisms would reduce employees' hypocritical $\mathrm{PEB}$, but only if the organisation genuinely cares about the environment. Our interview data cannot sufficiently illustrate how the interconnectedness of the two parties affect the emergence of hypocritical PEB at the organisational level, in which lower-level employees have little power to affect organisational decision making, due to the hierarchical structures existing in most contemporary organisations (Harley, 1999).

\section{Theoretical and practical implications and study limitations}

This study makes several contributions to the corporate and individual hypocrisy, CSR, and PEB literature streams. First, we provide the first parsimonious analysis of hypocritical PEB across levels, leveraging the multi-level theory of the legitimacy process to an attributional analysis of hypocritical PEB and thus overcoming the limits associated with single-level research and the heterogeneous theoretical frameworks applied to single-level analysis. Second, we enrich the hypocrisy literature within the PEB context by suggesting a theoretical distinction of the constructs substantive PEB, hypocritical PEB, and hypocritical behaviour that is not PEB-specific. Third, we deepen current understanding of the interplay between organisations and employees by conceptualising locus of responsibility and employeeorganisation alignment as two factors empowering the interconnectedness between them.

Our study suggests that organisations and employees walk a thin line between hypocritical and substantive PEB in the pursuit of legitimacy. However, we maintain that hypocritical PEB is a transitional phase in the long road to substantive PEB (Christensen, 
Morsing, \& Thyssen, 2013). Hypocritical PEB may be something that regulators and supervisors could attend to for its potential to turn into more substantive PEB. For example, employee hypocritical PEB can be transformed into substantive PEB by cultivating a habitual behavioural pattern that reinforces PEB (Steg \& Vlek, 2009). More important, organisations need to determine how to increase substantive PEB among those already motivated. They also need to pay more attention to the range of motives leading to these two types of PEB and explore ways to authentically move towards greater environmental protection. To manage hypocritical PEB at the employee level, we suggest that organisations appropriately address the locus of responsibility and employee-organisation alignment.

Last, this study is not without limitations. First, multi-level studies can overvalue homogeneity and underplay heterogeneity and independence across and/or within levels (Klein, Dansereau, \& Hall, 1994). For example, we did not explore employees' typologies based on their varying attitudes towards CSR (Rodrigo \& Arenas, 2008). That is, our employees likely possess heterogenous attitudes towards and interests in PEB. In addition, in line with the concept of equifinality from configurational theory (Doty, Glick, \& Huber, 1993), engagement in PEB may be due to multiple heterogenous reasons simultaneously. Second, the qualitative methodology employed herein has limitations. Although identifying hypocritical PEB at the organisational level may be easy (e.g., "the main reason that the sustainability team exists is to save university money" [SI11]), identifying hypocritical PEB in the case of employees based on interview data is more difficult. Previous research demonstrates a similar situation with regard to conspicuous green consumption, in which individuals were reluctant to admit that they engaged in such behaviours so as to exhibit social wealth and status (Griskevicius et al., 2010). Possible explanations for this include social desirability bias, ethical blind spots in decision making (individuals hold implicit biases, and their unconscious attitudes lead them to act against ethical principles without 
being aware of it; Banaji \& Greenwald, 2013), or self-serving biases (e.g., individuals subconsciously adjust their perceptions of right and wrong in a manner that better serves their self-interests without consciously realising it; Charness \& Haruvy, 2000). The concept of ethical blindness, which is also present in management research (Moberg, 2006), reflects systematic behavioural patterns by which organisational actors' moral capabilities are undermined in both managerial and individual decisions. As such, surveys, randomisedcontrolled studies, and even ethnographic and longitudinal research could offer further insights into the complex nature of hypocritical PEB. Third, additional research could compare hypocritical PEB in different contexts, such as that between non-profit and for-profit organisations. Hypocritical PEB is a rather complicated, multi-nuanced, and interesting phenomenon than current research acknowledges, but it is also one that requires further investigation. We therefore call for further research to employ a range of qualitative and quantitative research designs to help further demystify PEB, hypocritical or not. 


\section{Table 1}

Hypocritical PEB versus substantive PEB: key differences.

\begin{tabular}{|l|l|l|}
\hline Functions & Substantive PEB & Hypocritical PEB \\
\hline Self-interest & Secondary (if at all) & Primary \\
\hline Environmental concern & Primary & Secondary (if at all) \\
\hline Symbolic & No & Yes \\
\hline
\end{tabular}

Table 2

Data structure and findings (based on the Gioia methodology).

\begin{tabular}{|c|c|c|c|}
\hline Level & First-order concept & Second-order themes & Overarching themes \\
\hline \multirow{3}{*}{$\begin{array}{l}\text { Organisational-level } \\
\text { analysis }\end{array}$} & $\begin{array}{l}\text { - Control air pollution demanded by the Clean Air Act } \\
\text { - EU emission trading scheme } \\
\text { - Avoid legal risks of non-compliance } \\
\text { - Adopt ISO } 14001 \text { to signal legal compliance }\end{array}$ & Legal compliance & \multirow{4}{*}{ Legitimacy-seeking } \\
\hline & $\begin{array}{l}\text { - } \text { Carbon reduction targets set by HEFCE } \\
\text { Meet expectations of different stakeholders (e.g., } \\
\text { students, staff, community) } \\
\text { Provide leadership in the field of environmental } \\
\text { sustainability }\end{array}$ & Institutional forces & \\
\hline & $\begin{array}{l}\text { - Receive funding from HEFCE by achieving carbon } \\
\text { - } \text { Savission reduction targets } \\
\text { - } \text { Good PR } \\
\text { - Selling point for the university } \\
\text { - }\end{array}$ & Benefits to university & \\
\hline Employee-level analysis & $\begin{array}{l}\text { - Green initiatives organised by the central } \\
\text { sustainability team } \\
\text { Departments compete for Gold, Silver, and Bronze } \\
\text { accreditation awarded for green performance }\end{array}$ & $\begin{array}{l}\text { Compliance to workplace } \\
\text { initiative }\end{array}$ & \\
\hline
\end{tabular}




\begin{tabular}{|c|c|c|c|}
\hline & - Collective pressures from green ambassadors & & \\
\hline & $\begin{array}{l}\text { - Keep environment sterilised } \\
\text { - Strict rule on aircon usage } \\
\text { - Social norms for recycling } \\
\text { impression management }\end{array}$ & $\begin{array}{l}\text { Compliance to external } \\
\text { rules and norms }\end{array}$ & \\
\hline & $\begin{array}{l}\text { - Save costs for the university } \\
\text { - Less spending for the university leads to better } \\
\text { student experience } \\
\text { - Act on job roles }\end{array}$ & $\begin{array}{l}\text { Cost-saving for the } \\
\text { university }\end{array}$ & \\
\hline \multirow{3}{*}{$\begin{array}{l}\text { Interconnectedness of } \\
\text { organisational- and } \\
\text { employee-level analysis }\end{array}$} & $\begin{array}{l}\text { Emphasise the significance of employee } \\
\text { engagement } \\
\text { - Expect more student and staff engagement of green } \\
\text { initiatives }\end{array}$ & Employee engagement & \multirow{2}{*}{ Locus of responsibility } \\
\hline & $\begin{array}{l}\text { - Expect leadership from the top in driving PEB } \\
\text { Expect green initiatives to be one of the } \\
\text { organisational priorities }\end{array}$ & $\begin{array}{l}\text { Leadership and } \\
\text { proactiveness }\end{array}$ & \\
\hline & $\begin{array}{l}\text { - Value alignment in terms of viewing PEB as an } \\
\text { important and right thing to do } \\
\text { - Goal alignment in terms of viewing PEB as low } \\
\text { priority on work agenda } \\
\text { Job role alignment with regard to viewing PEB as } \\
\text { part of job }\end{array}$ & $\begin{array}{l}\text { Value/goal/interests } \\
\text { alignment }\end{array}$ & $\begin{array}{l}\text { Employee-organisation } \\
\text { alignment }\end{array}$ \\
\hline
\end{tabular}


Table 3

Examples to assess PEB.

\begin{tabular}{|c|c|c|c|c|}
\hline Level & Quotes (reason for PEB engagement) & Motivation & $\begin{array}{l}\text { Primary } \\
\text { reason }\end{array}$ & $\begin{array}{l}\text { Substantive } \\
\text { or } \\
\text { hypocritical } \\
\text { PEB? }\end{array}$ \\
\hline $\begin{array}{l}\text { Organisational-level } \\
\text { analysis example } 1\end{array}$ & $\begin{array}{l}\text { "So, the reason university } X \text { is interested in sustainability, }[\ldots] \text { is } \\
\text { because it reduces energy which saves the money. }[\ldots] \text { That's why } \\
\text { we're here. If we weren't saving money, I don't think that the } \\
\text { university would be that bothered." (SI11) }\end{array}$ & $\begin{array}{l}\text { Cost } \\
\text { reduction }\end{array}$ & Self-interest & $\begin{array}{l}\text { Hypocritical } \\
\text { PEB }\end{array}$ \\
\hline $\begin{array}{l}\text { Organisational-level } \\
\text { analysis example } 2\end{array}$ & $\begin{array}{l}\text { "Well, because we think it's important, mainly because we want to } \\
\text { offer the university a response to the global challenge of } \\
\text { sustainability." (SI13) }\end{array}$ & $\begin{array}{l}\text { Address } \\
\text { environmental } \\
\text { sustainability }\end{array}$ & $\begin{array}{l}\text { Environmental } \\
\text { concern }\end{array}$ & $\begin{array}{l}\text { Substantive } \\
\text { PEB }\end{array}$ \\
\hline $\begin{array}{l}\text { Employee-level } \\
\text { analysis example } 2\end{array}$ & $\begin{array}{l}\text { "For me I think it's personal responsibility. [...] If I see a colleague } \\
\text { put a piece of paper into a bin, I'll take it from the bin and take it to } \\
\text { recycling ... it's wasteful, not to reuse as much as you can. (XI02) }\end{array}$ & $\begin{array}{l}\text { Personal } \\
\text { responsibility; } \\
\text { Cost saving }\end{array}$ & $\begin{array}{l}\text { Environmental } \\
\text { concern }\end{array}$ & $\begin{array}{l}\text { Substantive } \\
\text { PEB }\end{array}$ \\
\hline
\end{tabular}


Fig. 1. A model of multi-level hypocritical PEB.

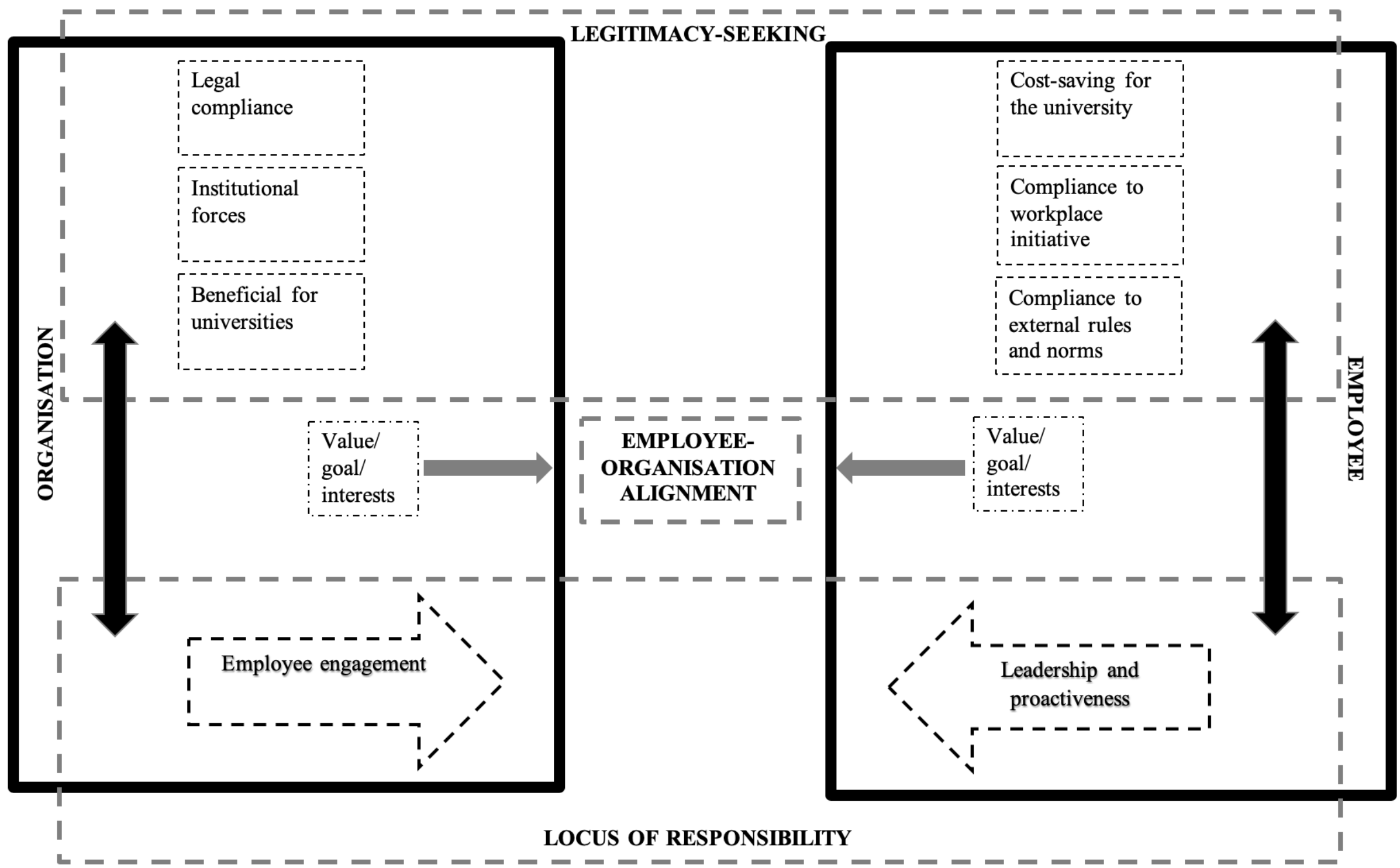




\section{References}

Agerholm, H., \& Agencies. (2017). Senior volkswagen employees charged over emissions scandal as company is handed \$4.3bn fine | The Independent. Retrieved October 22, 2018, from https://www.independent.co.uk/news/business/news/volkswagen-emissionsscandal-employees-charged-a7522801.html

Aguinis, H., \& Glavas, A. (2012). What we know and don't know about corporate social responsibility. Journal of Management, 38(4), 932-968.

https://doi.org/10.1177/0149206311436079

Akaah, I. P., \& Lund, D. (1994). The influence of personal and organizational values on marketing professionals' ethical behavior. Journal of Business Ethics, 13(6), 417-430. https://doi.org/10.1007/BF00881450

Aknin, L. B., Dunn, E. W., Helliwell, J. F., Biswas-Diener, R., Nyende, P., Barrington-Leigh, C. P., ... Norton, M. I. (2013). Prosocial spending and well-being: cross-cultural evidence for a psychological universal. Journal of Personality and Social Psychology, 104(4), 635-652. https://doi.org/10.1037/a0031578

Alvesson, M., \& Willmott, H. (2002). Identity regulation as organizational control: producing the appropriate individual. Journal of Management Studies, 39(5), 619-644. https://doi.org/10.1111/1467-6486.00305

Amiot, C. E., De La Sablonnire, R., Terry, D. J., \& Smith, J. R. (2007). Integration of social identities in the self: toward a cognitive-developmental model. Personality and Social Psychology Review, 11(4), 364-388. https://doi.org/10.1177/1088868307304091

Andreoni, J. (1989). Giving with impure altruism: applications to charity and ricardian equivalence. Journal of Political Economy, 97(6), 1447-1458.

https://doi.org/10.1086/261662 
Arvidsson, S. (2010). Communication of corporate social responsibility: a study of the views of management teams in large companies. Journal of Business Ethics, 96(3), 339-354. https://doi.org/10.1007/s10551-010-0469-2

Ashforth, B. E., \& Gibbs, B. W. (2008). The double-edge of organizational legitimation. Organization Science, 1(2), 177-194. https://doi.org/10.1287/orsc.1.2.177

Ashforth, B. E., \& Mael, F. (1989). Social identity theory and the organization. The Academy of Management Review, 14(1), 20. https://doi.org/10.2307/258189

Bamberg, S., \& Möser, G. (2007). Twenty years after Hines, Hungerford, and Tomera: a new meta-analysis of psycho-social determinants of pro-environmental behaviour. Journal of Environmental Psychology, 27(1), 14-25.

https://doi.org/https://doi.org/10.1016/j.jenvp.2006.12.002

Banaji, M. R., \& Greenwald, A. G. (2013). Blindspot: hidden biases of good people. New York: Delacorte Press.

Banerjee, S. B. (2012). Critical perspectives on business and the natural environment. In P. Bansal \& A. Hoffman (Eds.), The Oxford Handbook of Business and the Natural Environment (pp. 572-590). Oxford University Press.

Bansal, Pratima, \& Roth, K. (2000). Why companies go green: a model of ecological responsiveness. Academy of Management Journal, 43(4), 717-736. https://doi.org/10.2307/1556363

Barnett, M. L. (2007). Stakeholder influence capacity and the variability of financial returns to corporate social responsibility. The Academy of Management Review, 32(3), 794-816. https://doi.org/10.5465/AMR.2007.25275520

Batson, C. D., Thompson, E. R., Seuferling, G., Whitney, H., \& Strongman, J. A. (1999). Moral hypocrisy: appearing moral to oneself without being so. Journal of Personality and Social Psychology, 77(3), 525-537. https://doi.org/10.1037/0022-3514.77.3.525 
Berger, P. L., \& Luckmann, T. (1971). The social construction of reality: a treatise in the sociology of knowledge. Penguin Books.

Bitektine, A., \& Haack, P. (2015). The "macro" and the "micro" of Legitimacy: toward a multilevel theory of the legitimacy process. Academy of Management Review, 40(1), 49-75. https://doi.org/10.5465/amr.2013.0318

Blok, V., Wesselink, R., Studynka, O., \& Kemp, R. (2015). Encouraging sustainability in the workplace: a survey on the pro-environmental behaviour of university employees. Journal of Cleaner Production, 106, 55-67. https://doi.org/https://doi.org/10.1016/j.jclepro.2014.07.063

Boiral, O. (2007). Corporate greening through ISO 14001: a rational myth? Organization Science, 18(1), 127-146. https://doi.org/10.1287/orsc.1060.0224

Bowen, F. (2014). After greenwashing: symbolic corporate environmentalism and society. Cambridge: Cambridge University Press.

Brammer, S., Millington, A., \& Rayton, B. (2007). The contribution of corporate social responsibility to organizational commitment. International Journal of Human Resource Management, 18(10), 1701-1719. https://doi.org/10.1080/09585190701570866

Brewin, C. R., \& Shapiro, D. A. (1984). Beyond locus of control: attribution of responsibility for positive and negative outcomes. British Journal of Psychology, 75(1), 43-49. https://doi.org/10.1111/j.2044-8295.1984.tb02788.x

Brown, A. D. (1997). Narcissism, identity, and legitimacy. The Academy of Management Review, 22(3), 643-686.

Brunsson, N. (2002). The organization of hypocrisy: talk, decisions, and actions in organizations (2nd ed.). Copenhagen Business School Press. 
Butterfield, L. D., Borgen, W. A., Amundson, N. E., \& Maglio, A.-S. T. (2005). Fifty years of the critical incident technique: 1954-2004 and beyond. Qualitative Research, 5(4), 475-497. https://doi.org/10.1177/1468794105056924

Campbell, D. T. (1975). On the conflicts between biological and social evolution and between psychology and moral tradition. American Psychologist, 30(12), 1103-1126. https://doi.org/10.1037/0003-066X.30.12.1103

Carrington, M. J., Neville, B. A., \& Whitwell, G. J. (2014). Lost in translation: exploring the ethical consumer intention-behavior gap. Journal of Business Research, 67(1), 27592767. https://doi.org/10.1016/j.jbusres.2012.09.022

Charness, G., \& Haruvy, E. (2000). Self-serving biases: evidence from a simulated labour relationship. Journal of Managerial Psychology, 15(7), 655-667. https://doi.org/10.1108/02683940010378045

Chiaburu, D. S., Muñoz, G. J., \& Gardner, R. G. (2013). How to spot a careerist early on: psychopathy and exchange ideology as predictors of careerism. Journal of Business Ethics, 118(3), 473-486. https://doi.org/10.1007/s10551-012-1599-5

Cho, C. H., Laine, M., Roberts, R. W., \& Rodrigue, M. (2015). Organized hypocrisy, organizational façades, and sustainability reporting. Accounting, Organizations and Society, 40, 78-94. https://doi.org/10.1016/j.aos.2014.12.003

Christensen, L. T., Morsing, M., \& Thyssen, O. (2013). CSR as aspirational talk. Organization, 20(3), 372-393. https://doi.org/10.1177/1350508413478310

Clarkson, M. E. (1995). A stakeholder framework for analyzing and evaluating corporate social performance. Academy of Management Review, 20(1), 92-117. https://doi.org/10.5465/AMR.1995.9503271994 
Collier, J., \& Esteban, R. (2007). Corporate social responsibility and employee commitment. Business Ethics: A European Review, 16(1), 19-33. https://doi.org/10.1111/j.14678608.2006.00466.x

Colvin, A. J. S., \& Boswell, W. R. (2007). The problem of action and interest alignment: Beyond job requirements and incentive compensation. Human Resource Management Review, 17(1), 38-51. https://doi.org/10.1016/j.hrmr.2006.11.003

CRC energy efficiency scheme: qualification and registration. (2014). Retrieved February 20, 2018, from https://www.gov.uk/guidance/crc-energy-efficiency-scheme-qualificationand-registration

Creswell, J. W., \& Poth, C. N. (2017). Qualitative inquiry and research design: choosing among five approaches. ( $4^{\text {th }}$ ed.). SAGE Publications.

Dans, E. (2015). Volkswagen and the failure of corporate social responsibility. Retrieved February 19, 2018, from https://www.forbes.com/sites/enriquedans/2015/09/27/volkswagen-and-the-failure-ofcorporate-social-responsibility/\#495d2f724405

Davies, A., Fahy, F., \& Rau, H. (2014). Challenging consumption: pathways to a more sustainable future. Taylor and Francis.

Deckop, J. R., Cirka, C. C., \& Andersson, L. M. (2003). Doing unto others: the reciprocity of helping behavior in organizations. Journal of Business Ethics, 47(2), 101-113. https://doi.org/10.1023/A:1026060419167

Deegan, C., Rankin, M., \& Tobin, J. (2002). An examination of the corporate social and environmental disclosures of BHP from 1983-1997: a test of legitimacy theory. Accounting, Auditing \& Accountability Journal, 15(3), 312-343. https://doi.org/10.1108/09513570210435861 
DellaVigna, S., List, J. a, \& Malmendier, U. (2012). Testing for altruism and social pressures in charitable giving. Quarterly Journal of Economics, 127(1), 1-56.

https://doi.org/10.1093/qje/qjr050

Dermody, J., Koenig-Lewis, N., Zhao, A. L., \& Hanmer-Lloyd, S. (2017). Appraising the influence of pro-environmental self-identity on sustainable consumption buying and curtailment in emerging markets: evidence from China and Poland. Journal of Business Research, (October 2016), 0-1. https://doi.org/10.1016/j.jbusres.2017.09.041

Doty, D. H., Glick, W. H., \& Huber, G. P. (1993). Fit, equifinality, and organizational effectiveness: a test of two configurational theories. Academy of Management Journal, 36(6), 1196-1250. https://doi.org/10.2307/256810

Drever, E. (1995). Using semi-structured interviews in small-scale research: a teacher's guide. Scottish Council for Research in Education, Edinburgh.

Duarte, F. (2010). Working with corporate social responsibility in Brazilian companies: the role of managers' values in the maintenance of CSR cultures. Journal of Business Ethics, 96(3), 355-368. https://doi.org/10.1007/s10551-010-0470-9

Ellingsen, T., \& Johannesson, M. (2011). Conspicuous generosity. Journal of Public Economics, 95(9), 1131-1143.

https://doi.org/https://doi.org/10.1016/j.jpubeco.2011.05.002

Emerson, R. M. (1976). Social exchange theory. Annual Review of Sociology, 2, 335-362. https://doi.org/10.2307/2946096

Ferguson, E. (2015). Mechanism of altruism approach to blood donor recruitment and retention: a review and future directions. Transfusion Medicine, 25(4), 211-226. https://doi.org/10.1111/tme.12233

Fisher, R. J. (1993). Social desirability bias and the validity of indirect questioning. Journal of Consumer Research, 20(2), 303. https://doi.org/10.1086/209351 
Flanagan, J. C. (1954). The critical incident technique. Psychological Bulletin, 51(4), 327358. https://doi.org/10.1037/h0061470

Gibbs, G. R. (2008). Analysing qualitative data. Sage Publications.

Gioia, D. A., Corley, K. G., \& Hamilton, A. L. (2013). Seeking qualitative rigor in inductive research: notes on the Gioia methodology. Organizational Research Methods, 16(1), 15-31. https://doi.org/10.1177/1094428112452151

Glaser, B. G., \& Strauss, A. L. (1967). The discovery of grounded theory. Chicago: Aldine. Graham, J., Meindl, P., Koleva, S., Iyer, R., \& Johnson, K. M. (2015). When values and behavior conflict: moral pluralism and intrapersonal moral hypocrisy. Social and Personality Psychology Compass, 9(3), 158-170. https://doi.org/10.1111/spc3.12158

Greenbaum, R. L., Mawritz, M. B., \& Piccolo, R. F. (2015). When leaders fail to "walk the talk": supervisor undermining and perceptions of leader hypocrisy. Journal of Management, 41(3), 929-956. https://doi.org/10.1177/0149206312442386

Gregory, G. D., \& Leo, M. Di. (2003). Repeated behavior and environmental psychology: the role of personal involvement and habit formation in explaining water consumption. Journal of Applied Social Psychology, 33(6), 1261-1296. https://doi.org/10.1111/j.15591816.2003.tb01949.x

Griskevicius, V., Tybur, J. M., \& Van den Bergh, B. (2010). Going green to be seen: status, reputation, and conspicuous conservation. Journal of Personality and Social Psychology, 98(3), 392-404. https://doi.org/10.1037/a0017346

Hancock, K. (2005). Employee engagement partnerships: can they contribute to the development of an integrated CSR culture. Partnership Matters: Current Issues in Cross-Sector Collaboration, 3, 17-20. 
Harley, B. (1999). The myth of empowerment: work organisation, hierarchy and employee autonomy in contemporary Australian workplaces. Work, Employment and Society, 13(1), 41-66. https://doi.org/10.1177/09500179922117782

Hart, S. L. (1995). A natural-resource-based view of the firm. Academy of Management Review, 20(4), 986-1014. https://doi.org/10.5465/AMR.1995.9512280033

Hastings, P. D., Zahn-Waxler, C., \& McShane, K. (2006). We are, by nature, moral creatures: biological bases of concern for others. In Handbook of moral development. (pp. 483516). Mahwah: Lawrence Erlbaum Associates Publishers.

Highhouse, S., \& Gallo, A. (1997). Order effects in personnel decision making. Human Performance, 10(1), 31-46. https://doi.org/10.1207/s15327043hup1001_2

Hogg, M. A., \& Reid, S. A. (2006). Social identity, self-categorization, and the communication of group norms. Communication Theory, 16(1), 7-30. https://doi.org/10.1111/j.1468-2885.2006.00003.x

Hotten, R. (2015). Volkswagen: the scandal explained - BBC News. Retrieved June 19, 2017, from http://www.bbc.co.uk/news/business-34324772

ISO. (2018). ISO 14001: 2015 (en) Environmental management systems — requirements with guidance for use. Retrieved February 19, 2018, from https://www.iso.org/obp/ui/\#iso:std:iso:14001:ed-3:v1:en

Jahdi, K. S., \& Acikdilli, G. (2009). Marketing communications and corporate social responsibility (CSR): marriage of convenience or shotgun wedding? Journal of Business Ethics, 88(1), 103-113. https://doi.org/10.1007/s10551-009-0113-1

Kassinis, G., \& Vafeas, N. (2006). Stakeholder pressures and enviornmental performance. Academy of Management Review, 49(1), 145-159. https://doi.org/10.5465/AMJ.2006.20785799 
Kim, H., Hur, W., \& Yeo, J. (2015). Corporate brand trust as a mediator in the relationship between consumer perception of CSR, corporate hypocrisy, and corporate reputation. Sustainability, 7(4), 3683-3694. https://doi.org/10.3390/su7043683

Klein, K. J., Dansereau, F., \& Hall, R. I. (1994). Levels issues in theory development, data collection, and analysis. Academy of Management Review, 19(2), 195-229. https://doi.org/10.5465/AMR.1994.9410210745

Kristof, A. L. (1996). Person-organization fit: an integrative review of its conceptualizations, measurement, and implications. Personnel Psychology, 49(1), 1-49. https://doi.org/10.1111/j.1744-6570.1996.tb01790.x

Leygue, C., Ferguson, E., \& Spence, A. (2017). Saving energy in the workplace: why, and for whom? Journal of Environmental Psychology, 53, 50-62. https://doi.org/10.1016/j.jenvp.2017.06.006

Lindenberg, S., \& Steg, L. (2007). Normative, gain and hedonic goal frames guiding environmental behavior. Journal of Social Issues, 63(1), 117-137. https://doi.org/10.1111/j.1540-4560.2007.00499.x

Lipson, M. (2007). Peacekeeping: organized hypocrisy? European Journal of International Relations, 13(1), 5-34. https://doi.org/10.1177/1354066107074283

Mael, F. A., \& Ashforth, B. E. (1992). Alumni and their alma mater: a partial test of the reformulated model. Journal of Organizational Behavior, 13(2), 103-123. https://doi.org/10.1002/job.4030130202

Maigan, I., Ferrell, O. C., \& Hult, G. T. M. (1999). Corporate citizenship: cultural antecedents and business benefits. Journal of the Academy of Marketing Science, 27(4), $455-469$.

McCracken, G. (1988). The long interview. SAGE Publications, Inc. 
Mcshane, L., \& Cunningham, P. (2012). To thine own self be true? employees ' judgments of the authenticity of their organization's corporate social responsibility program. Journal of Business Ethics, 108(1), 81-100.

Mele, A. R. (2001). Self-deception unmasked. Princeton University Press.

Mirvis, P. (2012). Employee engagement and CSR: transactional, relational, and developmental approaches. California Management Review, 54(4), 93-117. https://doi.org/10.1525/cmr.2012.54.4.93

Moberg, D. J. (2006). Ethics blind spots in organizations: how systematic errors in person perception undermine moral agency. Organization Studies, 27(3), 413-428. https://doi.org/10.1177/0170840606062429

Morsing, M., \& Schultz, M. (2006). Corporate social responsibility communication: stakeholder information, response and involvement strategies. Business Ethics: A European Review, 15, 323-338. https://doi.org/10.1111/j.1467-8608.2006.00460.x

Muijenheidi, H. S. C. A. (2004). Corporate social responsibility starts at university. Journal of Business Ethics, 53(1-2), 235-246.

Norton, T. A., Zacher, H., \& Ashkanasy, N. M. (2014). Organisational sustainability policies and employee green behaviour: the mediating role of work climate perceptions. Journal of Environmental Psychology, 38, 49-54. https://doi.org/10.1016/j.jenvp.2013.12.008

People \& Planet University League. (2016). Retrieved March 10, 2017, from https://peopleandplanet.org/university-league

Porcu, L., Del Barrio-García, S., \& Kitchen, P. J. (2017). Measuring integrated marketing communication by taking a broad organisational approach: the firm-wide IMC scale. European Journal of Marketing, 51(3), 692-718. https://doi.org/10.1108/EJM-08-20150587 
Ramirez, E. (2013). Consumer-defined sustainably-oriented firms and factors influencing adoption. Journal of Business Research, 66(11), 2202-2209.

https://doi.org/10.1016/j.jbusres.2012.01.012

Ratner, R. K., \& Miller, D. T. (2001). The norm of self-interest and its effects on social action. Journal of Personality and Social Psychology, 81(1), 5-16. https://doi.org/10.1037/0022-3514.81.1.5

Reyniers, D., \& Richa, B. (2013). Reluctant altruism and peer pressure in charitable giving. Judgment and Decision Making, 8(1), 7-15.

Robertson, J. L., \& Barling, J. (2013). Greening organizations through leaders' influence on employees' pro-environmental behaviors. Journal of Organizational Behavior, 34(2), 176-194. https://doi.org/10.1002/job.1820

Rodrigo, P., \& Arenas, D. (2008). Do employees care about CSR programs? A typology of employees according to their attitudes. Journal of Business Ethics, 83(2), 265-283. https://doi.org/10.1007/s10551-007-9618-7

Schwartz, S. H. (1977). Normative influences on altruism. Advances in Experimental Social Psychology, 10, 221-279. https://doi.org/10.1016/S0065-2601(08)60358-5

Scott, W. R. (2014). Institutions and organisations: ideas, interests, and identities (6th ed.). SAGE Publications.

Shore, L. M. F., \& Wayne, S. J. (1993). Commitment and employee behavior: comparison of affective commitment and continuance commitment with perceived organizational support. Journal of Applied Psychology, 78(5), 774-780. https://doi.org/10.1037/00219010.78.5.774

Siano, A., Vollero, A., Conte, F., \& Amabile, S. (2017). "More than words": expanding the taxonomy of greenwashing after the Volkswagen scandal. Journal of Business Research, 71, 27-37. https://doi.org/10.1016/j.jbusres.2016.11.002 
Steg, L. (2005). Car use: lust and must. Instrumental, symbolic and affective motives for car use. Transportation Research Part A: Policy and Practice, 39(2-3 SPEC. ISS.), 147162. https://doi.org/10.1016/j.tra.2004.07.001

Steg, L., \& Vlek, C. (2009). Encouraging pro-environmental behaviour: an integrative review and research agenda. Journal of Environmental Psychology, 29(3), 309-317. https://doi.org/10.1016/j.jenvp.2008.10.004

Stern, P. C., Dietz, T., Abel, T., Guagnano, G. A., \& Kalof, L. (1999). A value-belief-norm theory of support for social movements: The case of environmentalism. Human Ecology Review, 6(2), 81-97. https://doi.org/10.2307/2083693

Suchman, M. C. (1995). Managing legitimacy: strategic and institutional approaches. Academy of Management Review, 20(3), 571-610. https://doi.org/10.5465/AMR.1995.9508080331

Swanson, D. L. (2014). Embedding CSR into corporate culture. London: Palgrave Macmillan UK.

Sweetin, V. H., Knowles, L. L., Summey, J. H., \& McQueen, K. S. (2013). Willingness-topunish the corporate brand for corporate social irresponsibility. Journal of Business Research, 66(10), 1822-1830. https://doi.org/10.1016/j.jbusres.2013.02.003

Tenbrunsel, A. E., \& Messick, D. M. (2004). Ethical fading: the role of self-deception in unethical behavior. Social Justice Research, 17(2), 223-236.

https://doi.org/10.1023/B:SORE.0000027411.35832.53

Thomas, K. A., DeScioli, P., Haque, O. S., \& Pinker, S. (2014). The psychology of coordination and common knowledge. Journal of Personality and Social Psychology, 107(4), 657-676. https://doi.org/10.1037/a0037037

Trivers, R. L. (1971). The evolution of reciprocal altruism. The Quarterly Review of Biology, 46(1), 35-57. https://doi.org/10.1086/406755 
Valentine, S., Godkin, L., \& Lucero, M. (2002). Ethical context, organizational commitment, and person-organization fit. Journal of Business Ethics, 41(4), 349-360. https://doi.org/10.1023/A:1021203017316

Vigoda-Gadot, E. (2007). Redrawing the boundaries of OCB? An empirical examination of compulsory extra-role behavior in the workplace. Journal of Business and Psychology, 21(3), 377-405. https://doi.org/10.1007/s10869-006-9034-5

Wagner, T., Lutz, R. J., \& Weitz, B. A. (2009). Corporate hypocrisy: overcoming the threat of inconsistent corporate social responsibility perceptions. Journal of Marketing, 73(6), 77-91. https://doi.org/10.1509/jmkg.73.6.77

Whiteman, G., Walker, B., \& Perego, P. (2012). Planetary boundaries: ecological foundations for corporate sustainability. Journal of Management Studies, 50(2), 307-336. https://doi.org/10.1111/j.1467-6486.2012.01073.x 
ONLINE SUPPLEMENTARY MATERIAL

Organisation and employee profiles

\begin{tabular}{|c|c|c|c|c|c|}
\hline & ID & Job category & Job title & $\begin{array}{l}\text { Organisa- } \\
\text { tion }\end{array}$ & $\begin{array}{l}\text { Level of } \\
\text { environmental } \\
\text { performance* }\end{array}$ \\
\hline \multirow{15}{*}{$\begin{array}{l}\text { Interviews } \\
\text { with } \\
\text { sustainability } \\
\text { managers to } \\
\text { investigate } \\
\text { organisation } \\
\text { al-level pro- } \\
\text { environment } \\
\text { al behaviours }\end{array}$} & 01 & Administrative & $\begin{array}{l}\text { Sustainability } \\
\text { coordinator }\end{array}$ & University 01 & First class \\
\hline & 02 & Executive & Head of sustainability & University 02 & First class \\
\hline & 03 & Administrative & Technical architect & University 03 & $2: 1$ class \\
\hline & 04 & Administrative & $\begin{array}{l}\text { Environmental } \\
\text { performance manager }\end{array}$ & University 04 & First class \\
\hline & 05 & Administrative & $\begin{array}{l}\text { Sustainable travel } \\
\text { coordinator }\end{array}$ & University 05 & $2: 2$ class \\
\hline & 06 & Executive & $\begin{array}{l}\text { Head of environment } \\
\text { and energy }\end{array}$ & University 06 & 2:1 class \\
\hline & 07 & Administrative & Sustainability officer & University 07 & First class \\
\hline & 08 & Administrative & $\begin{array}{l}\text { Sustainability } \\
\text { engagement coordinator }\end{array}$ & University 07 & First class \\
\hline & 09 & Administrative & $\begin{array}{l}\text { Sustainability } \\
\text { engagement officer }\end{array}$ & University 08 & First class \\
\hline & 10 & Executive & $\begin{array}{l}\text { Head of environmental } \\
\text { sustainability }\end{array}$ & University 09 & 2:1 class \\
\hline & 11 & Administrative & $\begin{array}{l}\text { Sustainability projects } \\
\text { officer }\end{array}$ & University 10 & $2: 2$ class \\
\hline & 12 & Administrative & $\begin{array}{l}\text { Sustainability and } \\
\text { engagement manager }\end{array}$ & University 10 & $2: 2$ class \\
\hline & 13 & Executive & $\begin{array}{l}\text { Head of energy and } \\
\text { sustainability }\end{array}$ & University 11 & 2:1 class \\
\hline & 14 & Administrative & Ground manager & University 12 & 2:1 class \\
\hline & 15 & Administrative & Sustainability manager & University 13 & First class \\
\hline \multirow{9}{*}{$\begin{array}{l}\text { Interviews } \\
\text { with } \\
\text { employees to } \\
\text { investigate } \\
\text { employee- } \\
\text { level pro- } \\
\text { environment } \\
\text { al behaviours }\end{array}$} & 01 & Academic & Research technician & \multirow[t]{9}{*}{ University X } & \multirow[t]{9}{*}{$2: 2$ class } \\
\hline & 02 & Administrative & $\begin{array}{l}\text { Student journey } \\
\text { manager }\end{array}$ & & \\
\hline & 03 & Administrative & Projects officer & & \\
\hline & 04 & Academic & $\begin{array}{l}\text { Postdoctoral research } \\
\text { fellow }\end{array}$ & & \\
\hline & 05 & Administrative & $\begin{array}{l}\text { Financial system } \\
\text { manager }\end{array}$ & & \\
\hline & 06 & Academic & $\begin{array}{l}\text { Lecturer in global } \\
\text { supply chain }\end{array}$ & & \\
\hline & 07 & Administrative & $\begin{array}{l}\text { Student experience and } \\
\text { support assistant }\end{array}$ & & \\
\hline & 08 & Administrative & $\begin{array}{l}\text { E-learning technology } \\
\text { officer }\end{array}$ & & \\
\hline & 09 & Administrative & $\begin{array}{l}\text { Directorate } \\
\text { administrator }\end{array}$ & & \\
\hline
\end{tabular}




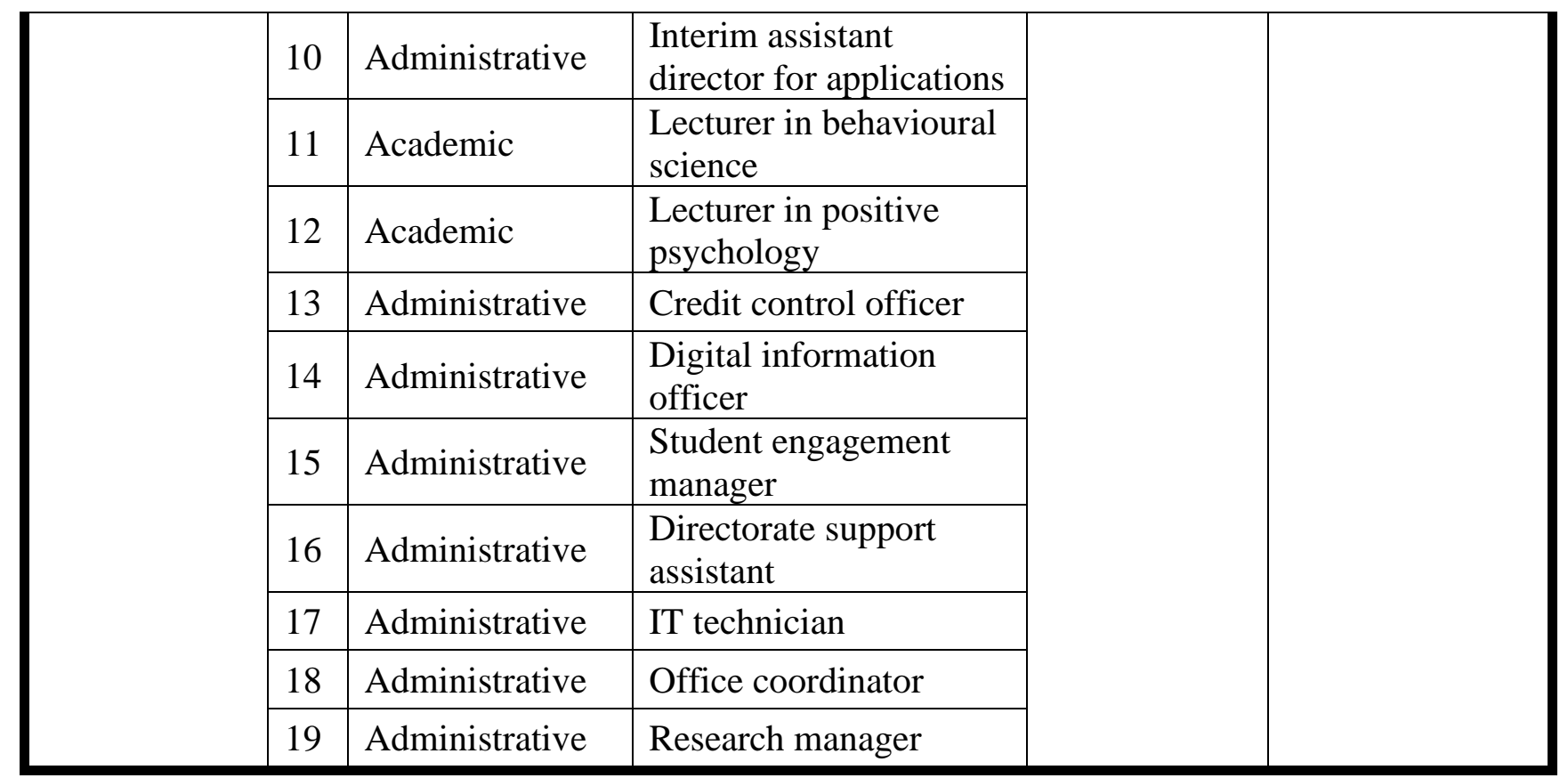

Note: Informants 07 and 08 from University 7 were interviewed simultaneously, according to their desire.

*Evaluations of each university's environmental performance are based on its ranking on the People \& Planet University League (2016) table. 


\section{Interview questions for sustainability managers}

A. Ice-breaking questions:

- Tell me a bit about your job and job responsibilities.

- What are your job objective and functions? What does this entail? What are your daily responsibilities or routine?

- Could you tell me about your department and XXX (name of organisation)?

\section{B. Does XXX engage in any environmental activities?}

(if the answer is yes, ask the questions below)

- Could you describe those activities?

[expecting answers to describe any environmental-related initiatives or programmes]

- What is the aim of those behaviours?

- What is the strategy to implement those programmes?

- How would you evaluate the performance/results?

- What do you think other universities do? Do they engage in the similar environmental activities? And why?

- What is the difference between what XXX does and what other universities do?

(if the answer is no, ask the questions below)

- Do you think XXX is expected to have environmental activities? And why?

- Do you think other universities are expected to have environmental activities? Why?

\section{Why do you think XXX engages in such behaviours?}

(if they talk about legislations or regulations, ask the questions below)

- What will happen if XXX does not do these activities?

- How would you evaluate those activities?

(if they talk about institutional expectations or pressures, ask the questions below)

- What will happen if XXX does not do these activities?

- What are the benefits for XXX to do these activities?

(if they talk about rewards or credentials, ask the questions below)

- In what ways did XXX be rewarded?

- What does the credential mean to XXX?

- What are the benefits for XXX to obtain such reward/credential?

(if those benefits they described relate to acquiring something or achieving something, ask the questions below)

- What does XXX try to acquire/achieve by doing these activities?

- How do these activities help XXX acquire/achieve $\mathrm{x}, \mathrm{y}, \mathrm{z}$ ?

- What are the outcomes after XXX acquiring/achieving $\mathrm{x}, \mathrm{y}, \mathrm{z}$ ?

(if those benefits they described relate to costs, ask the questions below)

- How do these activities save/increase costs?

- What are the influences of saved/increased costs on XXX?

(if they talk about leadership or authority, ask the questions below)

- What do these activities show to other universities?

- Do you know any environmental standards and codes that are applied in universities?

If yes: Do you think XXX has the power to influence those standards and codes of environmental performance? And how?

- Do you find that XXX is more likely or less likely to get positive evaluation of environmental performance? And why?

[Other information: Name of the organisation: XXX; Size; does it have an environmental management department?] 